\title{
Nadir'in Şah Eşref Hotekî ile Mücadelesi
}

\section{Sayed Shafiqula Sadat ${ }^{*}$}

\section{Özet}

İran'da Avşar Hanedanı'nı iktidara taşıyacak olan Nadir Şah, hâkimiyetini güçlendirmek için 1725 'te, önce Nisa'da Türkmenler, Habuşan'da Çemişgezek Kürtleri, Merv'de Özbekler, daha sonra Meşhed'de Melik Mahmud Sistanî'yi yenilgiye uğrattıktan sonra 1726'da da Meşhed ve Herat'ı ele geçirmiş, İsfahan'daki Afgan Hükümeti'ni ortadan kaldırmak amacıyla da Şah Eşref Hotekî ile savaşa karar vermiştir. İran'da hüküm süren Afgan Hükümeti'nin son iki yılında halktan topladığı ağır vergiler ve yaptığı yağmalara karşı halkın isyanı, ayrıca Melik Mahmud Sistanî ile Muhammed Fethali Kaçar gibi rakiplerini birer birer yenmesi, Nadir'in kalan tek düşmanı olan Şah Eşref Hotekî̀yi mağlup etmesini kolaylaştırmıştır. Bu arada Şah Eşref Hotekî'nin komutanı Seydal Han, Bistam'a ilerlerken kendisi de Simnan'ı kuşatarak Horasan sınırına dayanmıştır. Bu haberi öğrenen Nadir, 12 Eylül 1729'da Simnan'ın yardımına yetişmek üzere Meşhed'den ayrılarak Nişabur, Sebzevar yoluyla Şah Eşref Hotekî üzerine yürümüştür.

Bu makalede Nadir'in Şah Eşref Hotekî karşısındaki mücadelesi ve zaferi ele alınmıştır. Bu çerçevede İran'da kısa süren Afgan Hükümeti'nin son yıllarında İsfahan ve çevresinde yağma ve zülüm Nadir'in Galzaylar üzerine yürümesinin gerekçesini oluşturmuştur. Mücadelelerin neticesinde İran'da Afganlar, kendi hükümetini kaybettiği gibi Nadir ile yaptığı çetin savaşlarda büyük kayıp vermiştir. Bununla birlikte Nadir, Mir Mahmud Afgan tarafından İran'da tahttan indirilen II. Şah Tahmasb'ı tekrar tahta geçirip kendisi Galzaylar'ı İran sınırından dışarıya atmak amacıyla Deşt-i Zerkan'da Şah Eşref Hotekî üzerine yürümüştür. Şah Eşref Hotekî liderliğindeki Galzay savaşçıları ve sivil Afganlar savaşlar esnasında Afganistan'ın Kandahar Eyaleti'ne doğru kaçarken çoğu yolda hayatını kaybetmiştir. Ancak Kandahar'a kaçabilen Şah Eşref Hotekî'nin Zerdkoh yakınlarında öldürüldügü ifade edilmektedir. Nadir tarafından son savaşta yenilgiye uğratılan Galzaylar bir daha İran'a saldırma ve yağma yapmaya cesaret edememişlerdir.

Anahtar Kelimeler: Mehmandost Savaşı, derre-i Har Savaşı ve Murçe-i Hort Savaşı, Zerkan Savaşı

\footnotetext{
* Yüksek Lisans Öğrencisi, Sakarya Üniversitesi, Sosyal Bilimler Enstitüsü, Tarih Anabilim Dalı, Yeniçağ Tarihi Bilim Dalı, Sakarya, shafiq.sadat777@gmail.com. (Makale gönderim tarihi: 01.02.2017, makale kabul tarihi: 19.03.2017)
}

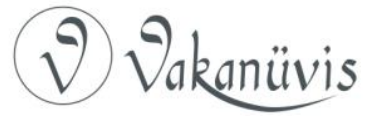




\title{
Nader's Battle with Shah Ashraf Hotaki
}

\begin{abstract}
Nader Shah who was to carry Afshar dynasty to power in Iran, after defeating Turkmens in Nisa, Çemişgezek Kurds in Habushan, Uzbeks in Merv in 1725, and after the defeat of Malek Mahmud Sistani in Mashhad, seized Mashhad and Herat in a bid to strengthen his dominance in 1726 and decided to battle Shah Ashraf Hotaki to remove Afghan power in Isfahan. The fact that Afghan dominance in Iran overtaxed people and caused resentment towards Afghans due to their pillages, also having defeated his rivals such as Malek Mahmud Sistani and Mohamed Fathali Kachar one after another, it became easy for Nader to defeat his only remaining enemy, Shah Ashraf Hotaki. In the meantime, while Shah Ashraf Hotaki's commander Seydal Khan was marching Bastam, Ashraf sieged Semnan and reached Horasan borders. After hearing this word, Nader left Mashhad and advanced upon Shah Ashraf Hotaki through Nishapur and Sabzevar on September $12^{\text {th }} 1729$ to reinforce Semnan.

In his article, I discussed Nader's struggle and victory against Shah Ashraf Hotaki. In this context, the pillage and the persecution that took place during the last years of short-winded Afghan dominance in Iran, became the basis for Nader's advance upon Ghilzais. After the battles with Nader, Afghans suffered heavy casualties as well as losing their dominance in Iran. However, Nader enthroned Shah Tahmasb II who was dethroned in Iran by Mir Mahmud Afghan, and advanced upon Shah Ashraf Hotaki in Dasht Zarkan to repel Ghilzais from Iran. Most of the Ghilzai combatants under Shah Ashraf Hotaki leadership and most of the Afghan civilians lost their lives while fleeing to Kandahar of Afghanistan during wars. Yet is said that Shah Ashraf Hotaki who was able to flee to Kandahar was killed near Zerdkoh. After being defeated in the last battle by Nader, Ghilzais did not venture attacking and pillaging Iran again.
\end{abstract}

Keywords: Mehmandost War, Darra Har War and Murçe Hort War, Zarkan War

Pek çok eserde Asya'nın son büyük cihangiri olarak tavsif edilen Nadir Şah, hükümdar olduğu dönemde (1736-1747) İran, Afganistan, Osmanlı ülkesi, Hindistan ve Batı Türkistan tarihinde derin izler bırakmıştır. ${ }^{1}$ iktidara gelmeden önce Horasan hâkimi Melik Mahmud

${ }^{1}$ Mehmet Alpargu, M. Bilal Çelik, “Nadir Şah’ın Batı Türkistan Seferi ve

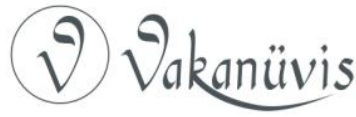


ile mücadelelerinde üst üste başarılı olup Şiilerin kutsal şehirlerinden biri olan Meşhed'i ele geçirmiş, ${ }^{2}$ böylece Şah II. Tahmasb dikkatini çekerek Safevi ordusunun komutanlığına atanmıştır. Sonra Tahmasbkulu Han unvanını alan Nadir, ${ }^{3}$ zaman zaman Horasan'ı istila eden Abdalîlerin ${ }^{4}$ üzerine sefer düzenleyerek Abdalî Hükümeti'nin merkezi Herat'a kadar ilerlemiştir. Herat ve Ferah illerini ele geçirdikten sonra İran'ın bir kısmına hâkim olan Şah Eşref Hotekî ${ }^{5}$ önderliğindeki Galzaylar ${ }^{6}$ ile mücadelelere kalkışan Nadir, İran'ın siyasi yapısında önemli değişiklere yol açarak İsfahan ve çevresini Galzaylardan temizlemiştir. ${ }^{7}$

Avşar Türkmenlerinden Kırklı Kabilesi, Özbek istilalarına karşı Meşhed'i savunmak için 16. yüzyılın başında, Şah Abbas döneminde Horasan'a göç ettirilmiştir. 28 Muharrem 1100/22 Kasım 1688 yılında Dezgird $^{8}$ köyünde bu kabilenin bir mensubu olan İmam Kulu Bey'in oğlu olarak dünyaya gelen Nadir, ${ }^{9}$ çocukluğu döneminde yaz aylarında

Sonuçları", Gazi Üniversitesi Gazi Eğitim Fakültesi Dergisi, c: 29, Temmuz 2009, s. 512.

2 Jonas Hanway, Zindegi-i Nadir Şah, Far. Çev. İsmail Devlet Şahi, Tahran, 1346 , s. 9.

${ }^{3}$ Norullah Larudi, Nadir Piseri Şemşir, Tahran, 1383, s. 46.

${ }^{4}$ Nadir Şah'ın öldürülmesiyle yani 1747 yılından itibaren Ahmet Şah Abdalî liderliğinde iki asırlık bağımsız bir devleti kuran Abdalîler ülkedeki Paştunların büyük aşiretlerinden birisi olup çoğunlukla tarım, hayvancilık ve ticaretle uğraşarak Kandahar, Herat ve çevresinde yaşamaktadırlar. bkz. Mir Gulam Muhammed Gubar, Afganistan der Mesir-i Tarih, Kabil, 1967, ss. 321-322.

${ }^{5}$ Şah Eşref Hotekî, Abdulaziz Hotekî'nin oğlu ve Galzayların lideri olan Mir Mahmud'un amcaoğludur. Bkz. M. Sıddik, Farhang, Afganistan der Panc Karn-ı Ahir, Meşhed 1993, s. 195-106; Gubar, 1967, s. 322.

${ }^{6}$ Galzaylar Afganistan'ın Paştun etnik grubuna mensup olup yeniçağda Surî ve Ludî adında Hindistan'a kadar bağımsız hükümetlerini sürdürmüştür. Konuyla daha detaylı bilgiler için bkz. Farhang, a.g.e., ss. 70-71.

7 Muhammed Kazım Mervi, Alemara-yı Nadiri; editör: Muhammed Emin Riyahi, c: 1, Tahran, 1364, s. 113.

${ }^{8}$ Dezgird ilinin bir köyü olan Ebiverd Horasan'ın kuzeyinde Türkmenistan sınırına yakın bir yerde bulunmaktadır.

${ }^{9}$ Kaynaklarda Nadir'in doğum tarihi ile ilgili farklı bilgiler verilmektedir. Örneğin Muhammed Kazım, Nadir'in doğum tarihini H. 1099 olarak kaydeder. Bkz Mervi, 1364, s. 7. Mirza Mehdi ise, Nadir'in 28 Muharrem 1100 'de

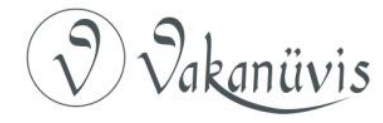


yaylada koyun sürüsü güttüğü ve kışın dericilik mesleğini icra eden babasına yardım ettiği ${ }^{10}$ ve küçük yaşta babasını kaybettiği, 14 yaşındayken yaşadığı bölgedeki diğer aşiretlerle mücadelelere katıldığı görülmektedir. Nitekim 1704'te Horasan bölgesini yağmalayan Özbekler tarafından annesi ile birlikte esir düşen Nadir 1708'de kaçarak Abiverd'e dönmüştür. ${ }^{11}$ Dört yıllık bir esaret hayatından sonra Horasan'a gelen Nadir önemli bir adım atarak, kendisi de Avşar Türklerinden olan Abiverd hâkimi Baba Ali Bey'in hizmetine girmiş, yeteneği ve cesareti ile Baba Ali Bey'in dikkatini çekerek önce "Eşikağası" sonra da "minbaşı (binbaşı)" makamına yükselmiştir. ${ }^{12} \mathrm{Kısa}$ sürede Abiverd muhafızlarının komutanı olan Nadir, Baba Ali'nin kızıyla evlenerek kayınbabasının hizmetinde kalmaya devam etmiştir. 1723 yılında Baba Ali'nin ölümüyle Abiverd valisi olan Nadir, günden güne bölgedeki hâkimiyetini güçlendirerek çevresindeki isyancıları kendisine tabi kılmıştır.

Nadir günden güne güçlenirken Safevi Devleti zeval bulmaktaydı. 1629 yılında I. Şah Abbas'ın ölümüyle yavaş yavaş zayıflayan Safevi Devleti, Şah Süleyman'ın 1668'de iktidara gelmesiyle birlikte bir anarşi ve buhran içine düşmüştür. ${ }^{13}$ Bu durumdan yararlanan Afganistan'ın güneybatısındaki Kandahar'da bulunan Galzay Devleti'nin İran sınırlarına kadar iktidarını genişlettiği ve zaman zaman İran'a saldırmaya çalıştı̆̆ı görülmektedir. Kandahar'da Mirveys Han önerdiğindeki Galzay Devleti, çevresindeki yerel feodal idarecilerin desteklerini kazanarak günden güne bölgede gücünü artırmakla bağımsız bir devlet haline gelmiştir. Ancak Mirveys'in vefat etmesiyle Galzay Devleti'nin başına oğlu Abdulaziz geçse de, onun yönetimi uzun süreli olmamıştır. Kandahar ve çevresinde kendini güvenceye alan Şah Mahmud harekete geçerek bu devletin yönetimini ele geçirmiş, müteakiben de Afganistan'ın siyasi ve idari birliğine odaklanmak yerine

doğduğunu kaydetmektedir. Bkz. Mirza Mehdihan, Esterabadi, Dürre-i Nadiri, C.1, ( Çev) Seyid Cafer Şehidi, Tahran, 1341. s. 7

${ }^{10}$ Hanway, a.g.e., ss. 8-9.

${ }^{11}$ Nadir esaret döneminde Hive'de kalmıştır. Bkz. Zeki Velidi Togan, Bugünkü Türkili Türkistan ve Yakın Tarihi, İstanbul, 1981, ss. 184-185.

${ }^{12}$ Nasir Necmi, Nadir Şah o'kab-i Kelat, Tahran, 1382, s. 29.

${ }^{13}$ Gubar, a.g.e., ss. 323-324.

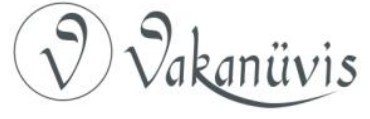


Safevi Devleti'nin içine düştüğü karışıklıktan faydalanarak doğrudan İran'a saldırmaya karar vermiştir. Bu arada derinden yozlaşmaya başlayan Safevi Devleti'nde bu durum artık son aşamaya gelmişti. Idarenin bozulmasından rahatsız olan ülke halkı devlete karşı Kürdistan, Şiraz, Bender-i Abbas, Belücistan ve Kirman bölgelerinde yaklanmalar gerçekleştirmişti. ${ }^{14}$

Ekim 1721'de emrindeki 28.000 Peştun, Özbek, Hazara ve Tacik askeriyle ve küçük bir topçu birliğiyle Kirman üzerine yürüyen Şah Mahmud, şehri ele geçirdikten sonra kaleye bir miktar muhafız bırakıp en güzide süvari kuvvetleriyle İsfahan üzerine yürümüştür. Safevi payitahtına 100 kilometre mesafedeki Varzene köyünde karargâhını kuran Şah Mahmud İsfahan'a ilerlemeye devam etmiştir. İtimadüddevle Muhammed Kulu Han, emrindeki yaklaşık 45 bin kişilik bir ordu ve 24 top ile İsfahan'dan Şah Mahmud'a karşı harekete geçmiştir. Nihayet 8 Mart 1722'de Genabad'da karşılaşan iki ordu arasında çetin bir savaş başlamıştır. ${ }^{15}$ Savaşta Şah Mahmud büyük kayıp vermesine rağmen mücadelesine devam ederek Afgan savaşçılarının başarılı saldırılarıyla payitahtın kapısına kadar ilerlemiş̧ir. Bu arada Şah II. Hüseyin kendisine dışarıdan bir türlü destek gelmeyince Şah Mahmud'a mücadeleyi bırakması için para ve mülk teklif etmiştir. Ancak bu teklifi kabul etmeyen Şah Mahmud payitaht kapılarını iki tarafından tutmuştur. Çaresiz kalan Şah Hüseyin, 12 Ekim 1722'de Şah Mahmud'a teslim olmaya karar vermiştir. Ferahabad'daki Mir Mahmud'un karargâhına gelerek Safevi tacını Mahmud'un başına takmıştır.

Böylece İran'da Safevi Devleti bir müddet için sona erip İran topraklarının bir kısmı Şah Mahmud önderliğindeki Afgan Hükümeti'nin yönetimi altına girmiş oldu. Şah Mahmud iki buçuk yıl süren hükümdarlığının ardından Şah Eşref Hotekî tarafından öldürülmüştür. ${ }^{16}$

${ }^{14}$ Farhang, a.g.e., s. 109.

15 Abdurrahman Ateş, Avşarlı Nadir Şah ve Döneminde Osmanlı-iran Mücadeleleri, Süleyman Demirel Üniversitesi Sosyal bilimler Enstitüsü Tarih Ana Bilim Dalı, Yayımlanmamış Doktora Tezi, Isparta, 2001, s. 44.

${ }^{16}$ Larudi, a.g.e., ss. 19-24.

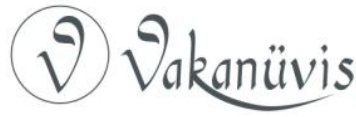


Bu süreçte Şah Mahmud'dan memnun olmayan Galzaylar ve komutanları ise Şah Eşref Hotekî'ye itaat ederek onun ordusuna katıldılar. Bu arada Kirman, Fars, Yezd, İsfahan ve Kaşan Afgan idaresi altındayken Şah Eşref Hotekî kendisine itaat etmeyen Mahmud'un muhafız alayı komutanı Illyas ve Yüzbaşı Emanullah'ı öldürerek diğer şehirleri ele geçirmeye çalışmaktaydı. Nadir böyle bir durumda Afganistan'ın batı ve güneybatısından gelen tehlikeleri önemli görmüş, önce Melik Mahmud ve sonra da Abdalîler üzerine harekete geçmiş, onları çetin savaşlarda yenilgiye uğratıp itaat altına aldıktan hemen sonra İsfahan'da Şah Eşref Hotekî önderliğindeki Galzaylara karşı mücadeleye başlamıştır. ${ }^{17}$ Şah Eşref Hotekî ise İran'daki hâkimiyetini daha güçlendirmek amacıyla Şah Hüseyin'in kızıyla nikâh yaptıktan sonra Osmanlılar ile 4 Ekim 1727'de imzaladığı Hemedan Antlaşması ile de Osmanlı Devleti'ne padişahlığını doğrudan kabul ettirmiştir. ${ }^{18}$ Şah Eşref bu antlaşma ile İran'ı batı tarafından güvenceye aldıktan sonra, Nadir'in Meşhed'i Melik Mahmud'dan, Herat'ı da Abdalîlerin elinden aldığını öğrenince süratle savaş hazırlıklarına başlayıp Bestam ve Simnan üzerinden iki koldan Nadir üzerine hücuma geçti. ${ }^{19}$ Şah Eşref Hotekî'nin Horasan'ın sınırlarına vardığını öğrenen Nadir, 12 Eylül 1729'da Simnan'ı kurtarmak için Meşhed'den ayrılarak Nişabur ve Sebzaver yoluyla Şah Eşref'in üzerine yürüdü. ${ }^{20} \mathrm{Bu}$ arada Şah Eşref Hotekî'nin komutanlarından biri olan Seydal Han, Bestam'da Nadir'in kuvvetlerinin bir kısmına yenilerek geri çekilmek zorunda kaldı. Bu gelişmeler üzerine Simnan kuşatmasını bırakan Şah Eşref Hotekî, Mehmandost köyüne çekilerek yeniden savaşa hazırlandı. Nihayet 29 Eylül 1729 'da Mehmandost'taki şiddetli çarpışmada Nadir'in topçu kuvvetleri Şah Eşref'in ordusunu bozguna uğrattı.

Şah Eşref, bu yenilgisinden sonra Tahran'dan asker toplayarak ikinci kez savaşa hazır olmuştur. Bu durumu öğrenen Nadir, sipahilerin bir kısmını Şah Eşref'in arkasından göndermiş, kendisi de doğrudan

\footnotetext{
${ }^{17}$ Rizazade, Şafık, Nadir Şah, Tahran, 1388, s. 3; Nacmi, a.g.e., s. 64.

${ }^{18}$ Gubar, a.g.e., s. 325.

19 Laurence Lockhart, A Critical Study Based Mainly Upon Contemporary Sources, London, 1938. s. 38.

${ }^{20}$ Ateş, a.g.t., s. 45.
}

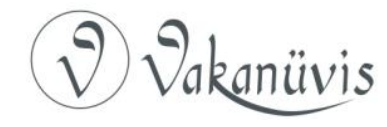


ilerleyerek Şah Eşref'in kuvvetlerine saldırmıştır. ${ }^{21}$ Böylece Nadir karşısında yine bozguna uğrayan Şah Eşref İsfahan'a kaçmıştır. Nadir tarafından üst üste iki kez yenilgiye uğratılmış olan Şah Eşref Hotekî İsfahan'da Şah II. Tahmasb kuvvetleriyle karşılaşmıştır. İsfahan'ı yağmalayan Şah Eşref Hotekî bir yandan tekrar savaşa hazırlanmış; diğer yandan Hemadan'da Osmanlı Devleti'nin muhafızı Abdurrahman Paşa'dan altın karşılığında 5.000 asker istemiştir. Ancak Abdurrahman Paşa bu teklifin karşısında Şah Eşref Hotekî̀ye yalnız 500 asker göndermiştir. ${ }^{22}$ Şah Eşref, topladığı kuvvetlerle birlikte Osmanlı kuvvetlerinden 500 askeri de yanına alarak İsfahan'dan Murçe-i Hort'a ${ }^{23}$ geçmiştir. Ancak Murçe-i Hort mevkiinde 12 Kasım 1729'da vuku bulan savaşta üçüncü kez mağlup edilmiştir. Ertesi gün Şah Eşref Hotekî İsfahan'daki ailesini ve hazinesini yanına alarak aceleyle Şiraz tarafına kaçtı. ${ }^{24}$ Daha sonra Şiraz'dan Zerkan'a, oradan da Belücistan'a gitmiştir. Nadir, Şah Eşref Hotekî'yi üç önemli savaşta yenerek 16 Kasım 1729 tarihinde İsfahan'a girdi ve Tahmasb'ı tekrar tahta geçirdi. ${ }^{25}$ Ancak Şah Eşref bu yenilgilerine rağmen Zerkan'da yeniden mücadelesine başlamıştır. Nadir Deştizerkan'da Şah Eşref Hotekî ve Galzayları son olarak ağır bir şekilde yenerek İran topraklarından uzaklaştırmıştır.

Buraya kadar genel hatlarıyla anlatılmaya çalışan mücadelelerin ayrıntılarına girelim.

\section{Mehmandost Savaşı}

Doğudan gelen tehlikeyi birinci derecede önemli görerek Melik Mahmud Sistani ve Abdalîlere karşı mücadele eden Nadir, onları üst üste mağlup edip etkisiz hale getirdikten sonra İsfahan'da Şah Eşref Hotekî liderliğindeki Galzayların üzerine yürümeye karar verdi. Nadir, Galzaylar'ı tamamen İran topraklarından uzaklaştırıp Şah II. Tahmasb'ı

\footnotetext{
${ }^{21}$ Esterabadi, a.g.e., s. 120.

${ }^{22}$ Larudi, a.g.e., ss. 66-67; Ateş, a.g.t., s. 46.

${ }^{23}$ Murçe-i Hort, İsfahan Eyaleti'nin Berhaver ilçesine bağı ıir semttir.

${ }^{24}$ Mervi, a.g.e., ss. 115-118; Abdulvahid Seyyidi, Nadir şah Afşar Horasani, Kabil, 1385, s. 41.

${ }^{25}$ Larudi, a.g.e., s. 74.
}

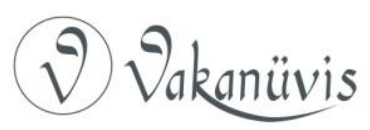


korumaya devam etti, üstelik onu aşağıda açıklanacağı gibi İsfahan'ı ele geçirdikten hemen sonra burada tekrar tahta oturtacaktır.

8 Nisan 1725'te Şah Mahmud'u öldüren Şah Eşref Hotekî, İsfahan'daki Galzay hükümetinin başına geçmiştir ve İran'da iktidarını güçlendirmek için Şah Hüseyin'in damadı olmuştur. Şah Eşref Hotekî, Osmanlı Hükümeti ile 4 Ekim 1727'de yaptığı bir antlaşması ile de Osmanlı Devleti'ne kendini İran Şahı olarak kabul ettirmiştir. Osmanlı Devleti'yle yaptığı Hamedan Antlaşması'yla batı tarafından kendisini güvenceye alan Şah Eşref Hotekî, Nadir'in Meşhed'i Melik Mahmud Sistani'den ve Herat'ı Abdalîlerinden aldığını öğrenince harp hazırlıklarına başlayıp süvari komutanı olan Seydal Han ile birlikte iki koldan harekete geçti. Onların Horasan sınırına vardığını öğrenen Nadir, 12 Eylül 1729 'da yaklaşık 30.000 kişilik bir orduyla Meşhed'den Mehmandost ${ }^{26}$ yakınlarına gelen Şah Eşref Hotekî'nin 45.000 kişilik ordusunun karşısına çıkmıştır. ${ }^{27}$ Nadir şu şekilde savaş nizamı almıştır:

- Gürcü Han komutasındaki birinci bölük cephenin sağ tarafında

- Hacı Han Bey komutasındaki ikinci bölük merkezde

- Serdar Ali Han Abdalî komutasındaki üçüncü bölük cephenin sol tarafında

6 Rebiulevvel 1142 (29 Eylül 1729)'de topçu sınıfını ve süvarileri yöneten Nadir, emri olmadan bu üç bölüğün askerlerinin hiçbir teşebbüste bulunmaması talimatını verdi. Böylece Nadir tam savaşa girerken Şah Eşref Hotekî hücuma geçerek Nadir'in ordusunun merkezine kadar ilerlemiştir. Bunun üzerine süvarilerine emir veren Nadir, Galzayların ilk saldırısını püskürttü. ${ }^{28}$ Ancak bu savaşta iki taraf da hiçbir netice elde edemedi. Ertesi gün Şah Eşref Hotekî'nin süvarileri ve piyadeleri Nadir'in topçu alayı tarafından top atışına maruz bırakılmalarına rağmen Galzaylar hücumlarına devam etmiştir. Nihayet Nadir, Şah Eşref Hotekî'nin kuvvetlerinin cüretkârlığını

${ }^{26}$ Mehmandost Simnan ilinin Tezre ilçesi kuzeyinde bulunan bir yerdir. Bkz. Mirza Mehdi Esterabadi, Cihangüşa-yı Nadiri, derleyen Mitra Mehrabadi, Tahran, 1390, s. 185.

${ }^{27}$ Larudi, a.g.e., s. 66; Ateş, a.g.t., s. 47.

${ }^{28}$ Hanway, a.g.e., ss. 31-32.

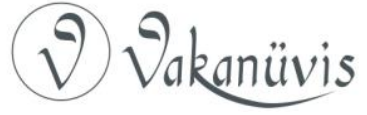


görünce süvarilerine savaş emri verip hızla Şah Eşref Hotekî kuvvetlerine yönelmiştir. Böylece kuşatılmış Şah Eşref Hotekî'nin ordusuna İran'ın topçuları da tepeden gülle yağdırdı. Ancak Şah Eşref Hotekî süvarilerin saldırısından büyük zarar gördüğünden bu saldırıda da istediği sonucu alamamıştır. ${ }^{29}$

Bu savaşta bir türlü netice elde edemeyen Nadir, yine ordusuna düzen verip kısa bir süre sonra Şah Eşref Hotekî kuvvetlerini bastırmak için onları arkadan kuşatarak kendisi Mehmandost kasabasının surunu top atışıyla yıktı. ${ }^{30} \mathrm{Bu}$ arada kasabanın arkasında sancakların etrafında savaşmakla meşgul olan Şah Eşref Hotekî'nin askerleri batıdaki tepelerden savaş meydanına ilerledi; ardından onun topçu alayı Nadir'in kuvvetlerini püskürtüp savaş meydanını terk etmelerine sebep olmuştur. Bu savaşta her iki taraf da büyük kayıplara uğrasa da, Şah Eşref Hotekî'nin kaybı daha büyük olmuş ve süvarilerini tamamen yitirmiştir. Şah Eşref Hotekî'nin bu yenilgiden sonra yapabileceği tek şey, dağılmış ve şaşırmış 10.000 kişilik ordusunu güçlükle derleyip yeniden bir araya getirerek Tahran yönüne kaçmaktı. Ama bu zafer Nadir için de zorlukla kazanılmışsa da, Galzayların moralinin bozulması Nadir'in ordusuna kazanma umudu vermiştir. ${ }^{31}$ Ayrıca Şah Eşref Hotekî'nin topçu birliğini ele geçirmek düşmanın son umudunu da bitirmiş oldu. Kazandığı zaferden sonra Nadir, kuzey illerinin ileri gelenlerine haber gönderip adamlarıla onun Firuz Kuh vadisinden Tahran-Meşhed'e giden yola ilerlemesi emrini verdi. Halk Mehmandost zaferini duyunca, genci ve yaşlısı Nadir'in ordusuna katılıp bayrağı altına girdiler. Sonra Nadir birkaç haberciyi daha kuzeybatıya, merkeze ve güneye gönderip zafer haberi ile daha parlak bir gelecek müjdesi verdi. $^{32}$

\footnotetext{
${ }^{29}$ Necmi, a.g.e., s. 64.

${ }^{30}$ Gubar, a.g.e., s. 335.

${ }^{31}$ Hanway, a.g.e., s. 30.

${ }^{32}$ Farhang, a.g.e., ss. 95-96; Larudi, a.g.e., s. 66.
} 


\section{Derre-i Har Savaşı}

Şah Eşref Hotekî, Mehmandost'ta yenildikten sonra Tahran yönüne kaçarken, öfkeden yol üzerinde olan kasabaları yıkıp masum insanları katletmiş ve Derre-i $\mathrm{Har}^{\prime} \mathrm{da}^{33}$ Nadir'le ikinci mücadele için 10.000 askeriyle ordugâhını kurdu. Tahran valisi olan İslam Han, Mehmandost Savaşı'nda Şah Eşref Hotekî'nin yenildiğini öğrenince 8000 askeri ve 9 hafif top ile Galzaylar'a yardım etmek için Derre-i Har'a doğru yola çıktı. Bu haberi duyan İran ordusunun komutanı olan Nadir, Damgan ve Simnan yoluyla altı günde Derre-i Har'a vardı. ${ }^{34}$ Ardından Mazendaran'dan diğer İran askerleri Nadir'in ordusuna katıldılar. Savaşa hazırlanan Nadir, Şah Eşref Hotekî'nin ordusunun yerini soruşturmasının ardından Şehid Vadisi üzerinden ordusunu geçirmeye kalktı. Ancak yolunun üzerindeki Galzayların saldırısına uğrayıp çok sayıda asker kaybı yaşayınca yenilme ihtimaline karşı, en iyi savaş taktiğini uygulamak gerektiğini düşünerek süvarilerinden bir kısmını çöl yolundan Derre-i Har boğazına gönderdi. Süvarilerin diğer kısmı ise önden Damavend ve Sorh Hisar'dan Derre-i Har'a doğru ilerledi. Bununla yetinmeyen Nadir, Sorh Hisar bölgesi halkı arasından topladığı askerleri Tahran'a doğru gönderdi. Nadir'in bu iki kısım ordusu Derre-i Har bölgesine yaklaşırken birleşti. Bu arada Nadir savaş meydanına yaklaşınca 14.000 kişilik ordusunu yine dört kısma ayırıp Derre-i Har ağzına hızla ilerledi. Ancak boğazın arkasında pusuda olan Şah Eşref Hotekî'nin bir grup askeri İran'ın piyade birliğine saldırıp onlardan birçoğunu öldürdü. Gece karanlığında gerçekleşen bu çatışmada, Nadir, ordusunda daha fazla can kaybı yaşanmaması için, Şah Eşref Hotekî'nin askerleri fark etmeden askerlerini geri çekerek bir araya getirdi. ${ }^{35}$ Savaş taktiklerine vakıf olan Nadir, Celal Han ve 200 cesur askerleriyle, şaşkın bir durumda olan Eşref Hotekî'nin kuvvetlerine arkadan baskın yaptı. Şah Eşref Hotekî liderliğindeki Galzaylar Nadir'in

\footnotetext{
33 Derre-i Har (Diken Vadisi), Tahran'ın birkaç kilometre doğusunda bulunan bir semttir. Şah Eşref Hotekî̀nin Nadir ile burada yapacağı savaşın nedeni ise Derr-i Har boğazının dar olması ve Nadir'in ordusunun vadiden dört grup olarak geçememesi ve Şah Eşref Hotekî'nin 18.000 kişilik ordusuyla çatışmaya mecbur kalmasıydı.

${ }^{34}$ Mirza Mehdi Esterabadi, Cihangüşa-yı Nadiri, 1390, s. 187.

${ }^{35}$ Larudi, a.g.e., s. 69.
}

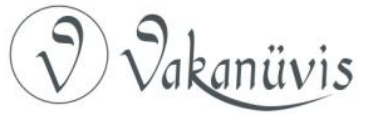


çetin baskınına dayanamayıp Derre-i Har'ın arkasındaki yerlere dağıldılar. Ardından Nadir kazandığı zafere mukabil ağır kayıplar vermiş olmasına rağmen Şah Eşref Hotekî̀in ordusunu tamamen yok etmek amacıyla yeniden savaş düzeni aldı.

Derre-i Har'da Nadir'in Galzaylar'a son saldırısı Kasım 1729'da gerçekleşti. Galzaylar tahkim edilmiş hisarlarından Nadir'in ordusuna hücuma başlayınca, Nadir askerlerini bu sefer üç kısma ayırıp üç yönden, yani sağ, sol ve merkezden saldırarak Şah Eşref Hotekî'nin ordusunu tamamen kuşattı. Bu korkunç ve kanlı savaşta Şah Eşref Hotekî çok sayıda askerini kaybederek, Derre-i Har'ın başına doğru çekilip Tahran yoluyla Kum'a yöneldi ve Nadir'le müteakip mücadeleler için askerî hazırlığa başladı. İran ordusu Galzaylar dağılmış tugaylarını Eyvanaki Vadisi'nin civarındaki dağlara kadar takip edip onların erzak ve teçhizatlarına el koydu. ${ }^{36}$

\section{Murçe-i Hort Savaşı}

13 Kasım 1729'da Nadir'in 32.000 süvari ve piyade asker ile topçu birliğinden oluşan ordusu Kum yoluyla Kaşan'a doğru harekete geçti. Altı gün sürekli yürüyerek Murçe-i Hort kasabasına ulaşıp savaş tertibi aldı. Bu arada Şah Eşref Hotekî'nin topçu birliği Murçe-i Hort'ın batı tepesinde üçüncü kez Nadir'in kuvvetlerine cephe aldı. Savaşa daha hazırlıklı olan bu ordunun komutanı Şah Eşref Hotekî iken süvari komutanı Seydal Han'dı ve bu ikincisine Tahran eski valisi i̇slam Han destek veriyordu. Ertesi gün savaş başladı ve her iki ordunun topçu birliği öğlene kadar durmadan ateş etti. Ancak iki taraftan da kimse göğüs göğse savaşa başlamak için öne çıkmıyordu. Öğleden sonra Nadir, kuvvetlerine Şah Eşref Hotekî'in ordusuna kılıçla savaşa başlama emri verdi ve Şah Eşref Hotekî'nin ordusuna doğrudan saldırdı. Ancak Şah Eşref Hotekî çok sayıda asker kaybı yaşamasına rağmen bu saldırıyı önlemede bir müddet için başarılı oldu. ${ }^{37}$

Ardından Nadir'in ordusu Şah Eşref'in kuvvetlerine bir defa daha saldırdı ve onları zor durumda bıraktı. Öyle ki, ölüme meydan okuyarak savaşıyorlardı. Nadir'in ordusu sağ cephedeki Şah Eşref Hotekî'nin kuvvetlerini önden, yandan ve arkadan kuşatmaya çabalarken

\footnotetext{
${ }^{36}$ Seyyidi, a.g.e., s. 43; Larudi, a.g.e., s. 67.

${ }^{37}$ Mervi, a.g.e., ss. 115-118; Larudi, a.g.e., s. 72.
}

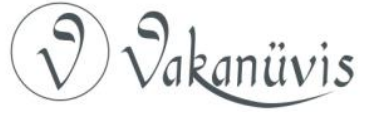


süvarileri meydanın arkasındaki Galzaylara saldırdı. Ardından Nadir'in piyadeleri de Şah Eşref Hotekî'nin kuvvetlerine merkezden baskın yapmaya başladı. Böylece katliam başlamış oldu. Ancak Şah Eşref Hotekî'nin kuvvetleri bir savaş taktiği ile dört bir taraftan Nadir'in ordusunu çevirmeye kalkıştı. Bunun üzerine çatışmayı tepeden izleyen Nadir, süvarilerinin dikkatsizliğini fark ederek muhafızları ile onlara yardıma koştu. Şah Eşref Hotekî'nin ordusunun coşku ve gayreti sayesinde savaşı kazanma ihtimali belirmişken, süvarilerin komutanı Seydal'ın dikkatsizliği nedeniyle çok asker kaybederek yenilmesi savaşın seyrini değiştirdi. Seydal'ın mücadelesini kaybettiğini öğrenen Şah Eşref Hotekî kalan tüm kuvvetleriyle Nadir'in ordusuna doğrudan saldırdı. Bu arada Hacı Han Bey, Şah Eşref Hotekî'nin süvarilerini pervasızca Nadir'e zarar vermesinden endişe duyarak, birkaç usta kılıçlı süvari grubunu Nadir'i korumaya gönderdi. Ertesi gün taraflar arasında bir kez daha çetin bir savaş başladı. Bu savaşta Şah Eşref Hotekî kendi kuvvetlerinin bir kısmının yok oluşunu görmesiyle telaşlanıp ölümden kurtulmak için savaş meydanını terk etti. ${ }^{38}$ Ayrıca son topçu birliğini de kaybedince, öfkeyle İsfahan'a doğru kaçtı. Böylece taraflar arasındaki savaş sona erdi. Nadir bu zaferden sonra Eşref ile işbirliği yapan, yakalanmış olan Osmanlı sipahilerinin silahlarını alıp onların ülkelerine dönmelerine izin verdi. Bundan sonra Şah II. Tahmasb'ı İsfahan'da tahta çıkardı. ${ }^{39}$

\section{Zerkan Savaşı}

Nadir, Şah II. Tahmasb'ı iktidara getirdikten hemen sonra dinlenmek için Meşhed'deki evine gitmek istedi. Tahta geçen Şah II. Tahmasb, Safevi Devleti'ne ait olan eski topraklara tekrar sahip olabilmek amacıyla, Rusları ve Osmanlıları ülkeden uzaklaştırma konusunda Nadir'den yardım istedi. Bu arada Şah Eşref Hotekî' liderliğindeki Galzaylar, İsfahan üzerine yürümek için hazırlanmaktaydı. Galzayların hazırlığını öğrenen Nadir, 20.000 kişilik bir orduyla Galzayları bastırmak için İsfahan'dan Meşhed'e doğru yola çıkmış ve Abarko yolundan Şah Eşref Hotekî'nin ordusunun bulunduğu

\footnotetext{
38 Şafık, a.g.e., s. 65; Mirza Mehdi Esterabadi, Cihangüşa-yı Nadiri, 1390, s. 188.

${ }^{39}$ Ateş, a.g.t., s. 46.
}

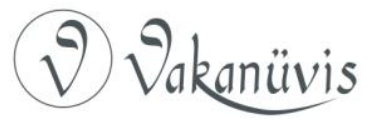


Zerkan'a $^{40}$ ilerledi. Daha önce üç kez Murçe-i Hort Savaşı'nda ağır yenilgiye uğrayan Şah Eşref Hotekî, Zerkan bölgesinde Nadir'in kuvvetleriyle karşılaştı. ${ }^{41}$ Galzaylar hemen Nadir'e saldırmış, piyadeler de Nadir'in ordusunu ikiye bölerek merkezine hücum etmişlerdir. İki tarafın orduları arasında zorlu bir savaş sürürken Nadir kendi topçularına, Şah Eşref Hotekî̀nin topçu birliğine ateş emri verdi. Ardından Nadir'in süvarileri bir hamle ile Şah Eşref Hotekî'nin ordusunu geri çekilmeye mecbur edip piyade birliğini bozduğu gibi 5.000 'den fazla Galzay'ı öldürdü. Kısa bir süre sonra da Şah Eşref Hotekî'nin kalan askerleri arasında anlaşmazlık ve ihtilaflar çıktı. ${ }^{42} \mathrm{Bu}$ durum ordunun bazı komutanlara itaat etmemesiyle sonuçlandı. Mağlubiyeti kesinleşince, Şah Eşref Hotekî muhafız alayı ile Şiraz şehrine kaçtı. Daha sonra Seydal, Şah Eşref Hotekî'nin temsilcisi olarak İsfahan'a Nadir'e gidip af isteyerek tabiiyet bildirdi. ${ }^{43}$ Bu teklifi kabul etmeyen Nadir, Galzayları Şiraz'dan da kovdu. ${ }^{44}$ Şiraz'dan ayrılan Galzaylar, Fisa köprüsünün çevresinde sığındılar. Kendisini çaresiz gören Şah Eşref Hotekî, barış istemek için Galzaylardan birini daha Nadir'in huzuruna gönderdi. Ancak Nadir Galzaylar'ın teklifini yine reddettiği gibi, Şah Eşref Hotekî'nin bizzat teslim olmasını söyledi. Nadir'e teslim olmayı reddeden Şah Eşref Hotekî, Nadir ile savaşmak için yine hazırlıklara başladı. Fisa köprüsüne yakın bir yerde gerçekleşen çatışmada Galzaylar yine büyük kayıp vererek dağıldılar. Nihayet Şah Eşref Hotekî, yanına ailesini ve bazı akrabaları ile bir miktar erzak alarak Gidar'a kaçtı. Bunun üzerine Nadir'in süvarileri peşlerine düşüp Gidar'a yöneldiler. Şah Eşref Hotekî'nin 5.000 askerlik ordusundan sadece Seydal ve kendisi ile 200 kişi canını kurtarabildi. Şah Eşref Hotekî'nin güneye kaçmasının ardından Nadir, Belücistan, Kirman ve Leristan halkına haber göndererek, Şah Eşref Hotekî'nin cesedini payitahta göndermelerini istedi. Şah Eşref Hotekî 200 askerle Lar'a girer girmez şehir halkının saldırısına uğrayıp tüm askerleri

40 Zerkan Şiraz'ın 33 kilometre uzaklığında bulunan bir yerdir. Bkz. Seyyidi, 1385 , s. 45.

${ }^{41}$ Mervi, a.g.e., s. 121.

${ }^{42}$ Ateş, a.g.t., s. 47.

${ }^{43}$ Larudi, a.g.e., s. 76.

${ }^{44}$ Azmi Özcan, "Nadir Şah ve Afganistan", Afganistan Üzerine Araştırmalar, Ali Ahmetbeyoğlu (der.), Tarih ve Tabiat Vakfı (TATAV) Yay., İstanbul, 2002, s. 46.

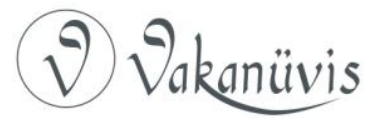


öldürülünce çaresiz ve aciz bir halde Belücistan'a kaçmaya mecbur kaldı. Nihayet İbrahim adında bir Afgan, Şah Eşref Hotekî'yi Belücistan'da olan Zardkoh çölünde yakalayarak öldürdü ve kellesini İsfahan'a gönderdi. ${ }^{45}$

Bu zaferden sonra Nadir askerlerin savaş ganimetlerine göz dikmemesi için bütün malzemeyi toplayıp yaktı. Sonra da payitaht İsfahan'a bir şölenle giriş yaptı. Halk 'Yaşa İran'ın büyük başkomutanı' diyerek bayrakları şehrin dört bir yanına diktiler. ${ }^{46}$

\section{Sonuç}

İsfahan'daki yedi senelik Galzay Hükümeti dönemi, İran'ın siyasi, iktisadi ve sosyal alanlarında derin izler bırakmıştır. Bu dönemde Nadir, Galzaylarla mücadele ettiği için İran'ın ekonomisi çok zarar gördüğü gibi üretim, ticaret ve sanayi düşüş yaşamıştır. Öyle ki, İsfahan ve çevresindeki halk işsiz kaldığı gibi açlık her yere yayılmıştı.

Şah Eşref Hotekîyle yapılan tüm mücadelelerde başarılı olan Nadir önce İran'daki Abdalîler ve Galzaylar'ı etkisiz hale getirdikten sonra ülkedeki kısa süreli Galzay Hükümeti'ne son vermiş ve Aralık 1729 da Şah II. Tahmasb'ı tekrar tahta geçirerek Safevi Devleti'ne can suyu olmuştur. Nadir, Şah Eşref Hotekî liderliğindeki Osmanlı askerlerini silahlarına el koyduktan sonra Osmanlı Devleti'ne iade etmiştir. İran'ın büyük komutanı olan Nadir, Şah Eşref Hotekî́yi Fisa'da dördüncü kez yenilgiye uğrattıktan sonra tüm Galzaylar'ı İran topraklarından uzaklaştırmıştır. Ayrıca Şah Eşref Hotekî'nin ordusundaki tüm askerî teçhizat ve topları ele geçirmiştir. Dolaysıyla Afganlar (Abdalîler ve Galzaylar) bir daha İran topraklarına saldırmaya ve yağma yapmaya cesaret edememiştir. Başkomutan Nadir, bu zaferden sonra Meşhed'e dönmüş ve şehir halkı tarafından büyük bir coşkuyla karşılanmıştır. Bu gelişmeler sayesinde büyük bir itibar gören Nadir'in, Osmanlılarla ve Ruslarla mücadele etmek için hazırlanmaya başladığını söyleyebiliriz.

\footnotetext{
${ }^{45}$ Ateş, a.g.t., s. 47; Hanway, a.g.e., s. 50.

${ }^{46}$ Nasir, a.g.e., s. 70; Larudi, a.g.e., s. 78.
}

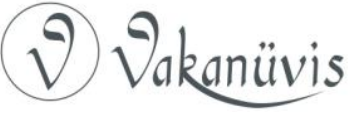




\section{Kaynakça}

Alpargu, Mehmet, M. Bilal Çelik, “Nadir Şah’ın Batı Türkistan Seferi ve Sonuçları", Gazi Üniversitesi Gazi Eğitim Fakültesi Dergisi, c: 29, Temmuz 2009.

Ateş, Abdurrahman, Avşarlı Nadir Şah ve Döneminde Osmanlı- Iran Mücadeleleri, Süleyman Demir Üniversitesi Sosyal Bilimler Enstitüsü Tarih Ana Bilim Dalı, Yayımlanmamış Doktora Tezi, Isparta, 2001.

Esterabadi, Mirza Mehdihan, Dürre-i Nadiri, yay. Seyid Cafer Şehidi, Tahran 1341. Şirketi İntişaratı Illmi ve Ferhengi Yay.,

Esterabadi, Mirza Mehdi, Cihangüşa-yı Nadiri, derleyen Mitra Mehrabadi, Dünyayı Kitab Yayınları, Tahran, 1390.

Farhang, M, Emin, Afganistan Der Penc Karn-i Ahir, İrfan Yayınları Meşhed, 1993.

Gubar, Mir Gulam Muhammed, Afganistan der Mesir-i Tarih, Matbaayı Devleti Yayınları, Kabil, 1967.

Jonas, Hanway, Zindegi-i Nadir Şah, Far. Çev. İsmail Devlet Şahi, Bengah-i Tercüme Neşri Kitab Yayınları, Tahran, 1346.

Larudi, Norullah, Nadir Piseri Şemşir, Dünyayı Kitab Yayınları, Tehran, 1383.

Laurence, Lockhart, A Critical Study Based Mainly Upon Contemporary Souces, Cambridge, 1938.

Mervi, Muhammed Kazım, Alemara-yı Nadiri, editör: Dr. Muhammed Emin Riyahi, 1. Cilt, İntişarat-ı IImi ve Ferhengi Yayınları Tahran, 1364.

Necmi, Nasir, Nadir Şah o'kab-i Kelat, Gotenberg Yayınları, Tahran, 1382.

Özcan, Azmi, "Nadir Şah ve Afganistan", Afganistan Üzerine Araştırmalar, Ali AHMETBEYOĞLU (der.), Tarih ve Tabiat Vakfı (TATAV) Yay., İstanbul, 2002.

Rizazade, Şafık, Nadir Şah, Veliesir Yayınları, Tahran, 1388.

Seyyidi, Abdulvahid, Nadir Şah Afşar Horasani, Kabil 1385. Meyvend yay.

Togan, Zeki Velidi, Bugünkü Türkili Türkistan ve Yakın Tarihi, Enderun Kitabevi Yayınları, İstanbul, 1981.

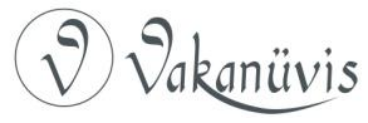

